\title{
KESALAHAN BERBAHASA TATARAN SINTAKSIS BIDANG KALIMAT PADA KOMENTAR YOUTUBE NAJWA SHIHAB MELAWAN CORONA
}

\author{
Wenty Agustin $^{* 1}$, M. Nur Mustafa ${ }^{2}$, Elvrin Septyanti $^{3}$ \\ Universitas Riau, Pekanbaru, Indonesia ${ }^{1,2,3}$ \\ wentyagustin31@gmail.com ${ }^{* 1}$, em_nur1388@yahoo.com², elvrin.septyanti@lecturer.unri.ac.id ${ }^{3}$
}

\begin{abstract}
This study aims to identify and describe the form of language errors at the syntactic level in the sentence field in the Youtube commentary of Najwa Shihab Melawan Corona. This type of research is qualitative or can be interpreted as research that emphasizes the quality of data collected using descriptive methods. Sources of data in this study are comments written by YouTube users on the Najwa Shihab Melawan Corona broadcast. The data in this study are writings that represent the opinions of Youtube users regarding related videos. The data collection techniques used in this study were reading and note-taking techniques. The data analysis technique used in this study was data reduction, data presentation, and conclusion drawing. The results of this study found language errors in the sentence field in the form of non-subjected sentences, non-predicated sentences, lucky sentences, duplication of subjects, illogical sentences, ambiguity sentences, conjunction omissions, Excessive use of conjunctions, unparalleled sequences, use of foreign terms and use of unnecessary question words.
\end{abstract}

Keyword : Sentence Field; Syntactic Level; Youtube Najwa Shihab Melawan Corona

\begin{abstract}
ABSTRAK
Penelitian ini bertujuan untuk mengidentifikasi dan mendeskripsikan bentuk kesalahan berbahasa tataran sintaksis dalam bidang kalimat pada komentar Youtube Najwa Shihab Melawan Corona. Jenis penelitian ini ialah penelitian kualitatif atau dapat diartikan sebagai penelitian yang menekankan kualitas data yang dikumpulkan dengan menggunakan metode deskriptif. Sumber data pada penelitian ini ialah komentar yang dituliskan pengguna Youtube pada siaran Najwa Shihab Melawan Corona. Data pada penelitian ini merupakan tulisan-tulisan yang merupakan pengutaraan pendapat para pengguna Youtube tehadap video terkait. Teknik pengumpulan data yang digunakan dalam penelitian ini ialah teknik baca dan teknik catat. Teknik analisis data yang digunakan pada penelitian ini reduksi data, penyajian data, penarikan kesimpulan. Hasil dari penelitian ini ditemukan kesalahan berbahasa dalam bidang kalimat pada bentuk kalimat tidak bersubjek, kalimat tidak berpredikat, kalimat buntung, penggandaan subjek, kalimat tidak logis, kalimat ambiguitas, penghilangan konjungsi, penggunaan konjungsi yang berlebihan, urutan yang tidak paralel, penggunaan istilah asing dan penggunaan kata tanya yang tidak perlu.
\end{abstract}

Kata Kunci : Bidang Kalimat; Tataran Sintaksis; Youtube Mata Najwa Melawan Corona

\section{PENDAHULUAN}

Penggunaan aplikasi pada ponsel pintar secara umum bertujuan untuk membantu dalam berinteraksi sosial dan dapat mendukung penyebaran informasi yang dibutuhkan oleh manusia. Bukan saja akses informasi yang didapatkan dari penggunaan aplikasi, tetapi juga akses dalam menyuarakan pendapat pada setiap topik yang menjadi pembahasan. Aplikasi Youtube merupakan salah satu aplikasi yang mendukung penggunanya dalam menyuarakan pendapat, hal ini terbukti dengan tersedianya fitur kolom komentar. Akses dalam menyampaikan komentar di Youtube terbilang 
mudah sehingga siapapun dapat melakukannya.

Kemudahan akses dalam berkomentar di Youtube terkadang menimbulkan polemik baru, salah satunya tidak selarasnya pemahaman yang ditangkap oleh pembaca terhadap tulisan yang ditinggalkan oleh pengguna yang berkomentar. Kalimat sangat dibutuhkan agar keselarasan pemahaman antara pembaca dan penulis dapat terjalin dengan baik. Keselarasan pemahaman ini pula yang menghantarkan pembaca dapat menerima dengan baik maksud yang ingin disampikan oleh penulis. Setiap tulisan yang tersusun secara baik dan lengkap akan mudah dimengerti oleh pembacanya (Sinaga, 2017). Ilmu yang bernama sintaksis memagang fungsi penting dalam hal ini. Mulai dari subjek, predikat, objek, pelengkap, dan keterangan harus saling padu

Ramlan dalam (Setyawati, 2013) mendefinisikan sintaksis sebagai bagian atau cabang dari ilmu bahasa yang membicarakan seluk beluk wacana, kalimat, klausa, dan frasa; berbeda dengan morfologi yang membicarakan seluk beluk kata dan Morfem. sintaksis berfokus atau menekankan bagaimana seluk beluk kalimat yang dapat membantu dalam pemahaman sebuah gagasan yang disampaikan oleh penulis. Penulis dalam hal ini ialah para pengguna youtube yang meninggalkan pendapatnya pada kolom komentar yang telah disediakan. Penelitian ini berfokus kepada tataran sintaksis bidang kalimat, kalimat adalah satuan bahasa terkecil, dalam wujud lisan dan tulisan, yang mengungkapka pikiran yang utuh (Alwi, 1989). Menurut (Alisjahbana, 1978) kalimat ialah satuan kumpulan kata yang terkecil yang mengandung pikiran yang lengkap. Menurut (Chaer, 2003) kalimat adalah satuan bahasa yang berisi "pikiran" dan "amanat" yang lengkap. Kalimat juga merupakan ucapan bahasa yang memiliki arti dan turunnya suara menjadi cirinya sebagai batas keseluruhannya (Fokker, 1978). Kesalahan berbahasa tataran sintaksis dalam bidang kalimat terdiri atas 12 bentuk kesalahan, yaitu : (1) Kalimat tidak bersubjek (2) Kalimat tidak berpredikat (3) Kalimat tidak bersubjek dan tidak berpredikat (kalimat buntung) (4) Penggandaaan subjek (5) Antara predikat dan objek yang tersisipi (6) Kalimat yang tidak logis (7) Kalimat yang ambigiuitas (8) Penghilangan konjungsi (9) Penggunaan konjungsi yang berlebihan (10) Urutan yang tidak paralel (11) Penggunaan istilah asing (12) Penggunaan kata tanya yang tidak perlu (Setyawati, 2013).

Peneliti sangat tertarik dengan komentarkomentar pengguna YouTube terutama pada YouTube Najwa Shihab karena kemudahan akses dalam meninggalkan komentar serta isu yang diangkat merupakan topik yang sedang hangat untuk diperbincangkan. Youtube Najwa Shihab yang berfokus mengangkat isu politik ataupun sosial, membuat penulis tertarik menganalisis kalimat yang ditinggalkan oleh masyarakat dalam kolom komentar tersebut. Kalimat yang dituliskan bukan saja tertuju pada pemerintah namun juga tertuju kepada sesama masyarakat yang bersifat saling mengingatkan. Keberagaman latar belakang kehidupan dan pendidikan masyarakat yang berkomentar juga menjadi daya tarik tersendiri. Keberagaman ini juga menjadi salah satu faktor beragamnya kesalahan berbahasa bidang kalimat yang terdapat dalam tataran sintaksis yang ditemukan. Berdasarkan pemaparan tersebut penulis memberi judul penelitian yaitu Kesalahan Berbahasa Tataran Sintaksis dalam Bidang Kalimat pada Komentar Youtube Najwa Shihab Melawan Corona. Tujuan penelitian ini dilakukan ialah untuk mengidentifikasi dan mendeskripsikan bentuk kesalahan berbahasa dalam bidang kalimat pada komentar Youtube Najwa Shihab Melawan Corona.

\section{METODOLOGI PENELITIAN}

Jenis penelitian ini ialah penelitian kualitatif atau dapat diartikan sebagai penelitian yang menekankan kualitas data yang dikumpulkan. Penelitian ini menggunakan metode deskriptif dalam pengolahan datanya. Metode yang dilakukan dengan jalan menganalisis data yang sudah dikumpulkan berupa kata-kata, gambar dan bukan angkaangka. Metode deskriptif dapat diartikan sebagai prosedur pemecahan masalah yang diselidiki dengan menggambarkan atau melukiskan keadaan atau objek penelitian pada saat sekarang berdasarkan fakta-fakta yang tampak (Moleong, 2007). Menurut (Gani, 2019) metode deskripif ialah bertujuan menemukan informasi sebanyak-banyaknya dalam suatu 
fenomena. Menggunakan metode deskriptif peneliti berharap dapat melakukan penganalisisan dengan tepat, karena penelitian ini berfokus kepada data yang berupa kata-kata dan bukan merupakan data yang berbentuk angka, sehingga peneliti menetapkan metode deskriptif adalah metode yang tepat untuk digunakan.

Sumber data pada penelitian ini ialah komentar yang dituliskan pengguna Youtube pada siaran Najwa Shihab melawan Corona. Peneliti mendapatkan sumber data komentar dari total 7 bagian video. "Melawan Corona: Cerita Tetangga Pasien 01 dan 02 (Part1)", "Melawan Corona : Seberapa Siap Pemerintah Menghadapi Corona (Part2)", "Melawan Corona: Mencoba Hotline Virus Corona (Part 3)", "Melawan Corona: Beda Singapura-Indonesia Cegah Corona (Part 4)", "Melawan Corona: Tangani Corona Dana Kemenkes Separuh Dana Influencer (Part 5)", "Melawan Corona: Tes Virus Corona Perlu Biaya Mahal ? (Part 6)", serta "Melawan Corona: Fakta atau Dusta Corona (Part 7)".

Teknik pengumpulan data yang pertama digunakan ialah teknik baca, dengan langkah yaitu, (1) Mencari saluran Youtube Najwa Shihab yang berjudul Melawan Corona yang terbagi menjadi 7 bagian video. (2) Memutar satu persatu bagian video karena kolom komentar dapat diakses jika video diputar. (3) Melakukan tangkapan layar terhadap komentarkomentar pada video Youtube Najwa Shihab Melawan Corona. (4) Mengidentifikasi data kesalahan pada setiap tangkapan layar terhadap komentar-komentar tersebut. Teknik berikutnya ialah teknik catat dengan langkah yaitu, (1) Mencatat hasil identifikasi kesalahan berbahasa tataran sintaksis pada komentar youtube Najwa Shihab Melawan Corona. (2) Mengelompokkan hasil pada bentuk kesalahan berbahasa tataran sintaksis dalam bidang kalimat. Hal berikutnya yang dilakukan ialah menganalisis data dengan beberapa langkah yaitu, (1) Data Reduction (Reduksi Data) (2) Data Display (Penyajian Data) (3) Conslusions Drawing/verification (Penarikan Kesimpulan) (Sugiyono, 2012).

\section{HASIL DAN PEMBAHASAN}

Penelitian oleh (Sebayang, 2019) STKIP

Budidaya Binjai yang berjudul "Analisis
Kesalahan Berbahasa pada Sosial Media Instagram Dalam Postingan, Komentar dan Cerita Singkat" merupakan salah satu penelitian yang relevan dengan penelitian ini. Persamaan penelitian oleh Sri Kurnia Hastuti Sebayang dan Anita Soleha Sofyan dengan penelitian ini ialah menganalisis kesalahan berbahasa serta objek yang digunakan, salah satu objek yang berupa komentar relevan dengan objek pada penelitian ini yang juga berupa komentar. Perbedaannya terletak pada sumber komentar yang dijadikan objek penelitian yaitu Intsagram dan Youtube.

Penelitian relevan lainnya ialah penelitian oleh (Setiawan \& Zyuliantina, 2020) Universitas PGRI Madiun yang berjudul "Analisis Kesalahan Berbahasa Indonesia pada Status dan Komentar Facebook". Persamaan penelitian oleh Kodrat Eko Putro Setiawan dan Wixke Zyuliantina dan penelitian ini ialah analisis kesalahan berbahasa dan objek yang digunakan yaitu berupa komentar. Perbedaannya terletak pada sumber objek yang berupa Facebook dan Youtube. Analisis kesalahan berbahasa pada penelitian yang relevan ini berfokus kepada penggunaan pada huruf, tata tulis pada kata, dan penggunaan pada tanda baca sedangkan penelitian "Kesalahan Berbahasa Tataran Sintaksis Bidang Kalimat Pada Komentar Youtube Najwa Shihab Melawan Corona" berfokus kepada tataran sintaksis sebagai pijakan yang digunakan sebagai dasar dalam menganalisis.

Berdasarkan hasil identifikasi, dari 12 bentuk kesalahan berbahasa tataran sintaksis dalam bidang kalimat terdapat 11 bentuk yang datanya ditemukan.

\section{Kalimat Tidak Bersubjek}

Berdasarkan hasil identifikasi, ditemukan sembilan data kesalahan dalam bidang kalimat pada bentuk kalimat tidak bersubjek.

"Terlebih ketika di bandara, tdk ada kebijakan pencegahan penyebaran virus."

Data di atas termasuk kesalahan berbahasa dalam bidang kalimat pada bentuk kalimat tidak bersubjek. Kalimat tidak bersubjek dapat diidentifikasi jika predikat pada kalimat tersebut dijadikan tumpuan dalam pertanyaan. Tumpuan 
untuk mengajukan pertanyaan, dapat mengggunakan kata tanya apa yang ? atau siapa yang ? Misalnya, "Siapa yang tidak memberikan kebijakan pencegahan virus di bandara?"

Berdasarkan pertanyaan "Siapa yang tidak memberikan kebijakan pencegahan virus di bandara ?", jawaban pada data di atas tidak ditemukan fungsi subjek. Dengan demikian, data tersebut termasuk kesalahan berbahasa pada bentuk kalimat tidak bersubjek. Perbaikan kalimat tersebut dapat menetapkan subjek berupa "pemerintah" karena dilihat dari judul video yaitu Melawan Corona : Seberapa Siap Pemerintah Menghadapi Corona (Part2) pengguna Youtube yang meninggalkan komentar menjadikan pemerintah sebagai sasaran dalam berkomentar. Perbaikan kalimat data tersebut seharusnya :

"Terlebih ketika di bandara, pemerintah tidak ada memberikan kebijakan pencegahan penyebaran virus."

Data lainnya ialah :

"Harus melakukan pengetesan lbh byk lagi."

Data di atas termasuk kesalahan berbahasa dalam bidang kalimat pada bentuk kalimat tidak bersubjek. Kalimat tidak bersubjek dapat diidentifikasi jika predikat pada kalimat tersebut dijadikan tumpuan dalam pertanyaan. Tumpuan untuk mengajukan pertanyaan, dapat mengggunakan kata tanya apa yang ? atau siapa yang ? Misalnya, "Siapa yang harus melakukan pengetesan lebih banyak lagi ?"

Berdasarkan pertanyaan "Siapa yang harus melakukan pengetesan lebih banyak lagi ?", jawaban pada data di atas tidak ditemukan fungsi subjek. Dengan demikian, data tersebut termasuk kesalahan berbahasa pada bentuk kalimat tidak bersubjek. Perbaikan kalimat tersebut dapat menetapkan subjek berupa "pemerintah" karena dilihat dari judul video yaitu Melawan Corona : Seberapa Siap Pemerintah Menghadapi Corona (Part2) pengguna youtube yang meninggalkan komentar menjadikan pemerintah sebagai sasaran dalam berkomentar. Perbaikan kalimat data (3) seharusnya :
"Pemerintah harus melakukan pengetesan lebih banyak lagi."

\section{Kalimat Tidak Berpredikat}

Berdasarkan hasil identifikasi, ditemukan satu data kesalahan dalam bidang kalimat pada bentuk kalimat tidak berpredikat.

"Masker hanya untuk yang sakit."

Predikat merupakan salah satu unsur penting dalam terbentuknya sebuah kalimat. Berdasarkan teori analisis kesalahan berbahasa yang digunakan, penulisan atau pengucapan kalimat tidak berpredikat dapat terjadi karena penulis ataupun pembicara lupa serta terlena terhadap penggunaan unsur predikat. Penyebab lainnya kalimat tidak berpredikat ialah penggunaan keterangan subjek yang terlalu beruntun atau panjang. Perbaikan data kesalahan berbahasa di atas ialah :

"Masker hanya digunakan untuk yang sakit."

\section{Kalimat Tidak Bersubjek dan Tidak Berpredikat (Kalimat Buntung)}

Berdasarkan hasil identifikasi, ditemukan lima data kesalahan dalam bidang kalimat pada bentuk kalimat tidak bersubjek dan tidak berperdikat (kalimat buntung).

"Ingat masa inkubasi corona, jangan merasa sehat setelah 14 hari lebih bisa saja virus sudah menyebar. Dan semua menyalahkan pemerintah.'”

Data di atas termasuk bentuk kesalahan dalam bidang kalimat pada bentuk kalimat tidak bersubjek dan tidak berpredikat (kalimat buntung). Berdasarkan teori analisis kesalahan berbahasa tataran sintaksis yang digunakan, kata dan yang dicetak miring merupakan kalimat buntung yang fungsi sebenarnya ialah sebagai keterangan bagi kalimat sebelumnya. Kalimat yang di awali dengan konjungsi dan seharusnya menjadi anak kalimat bagi kalimat sebelumnya. Perbaikan kalimat di atas seharusnya :

"Ingat masa inkubasi corona! Jangan 
merasa sehat setelah 14 hari lebih. Bisa saja virus sudah menyebar dan semua menyalahkan pemerintah."

\section{Penggandaan Subjek}

Berdasarkan hasil identifikasi, ditemukan satu data kesalahan dalam bidang kalimat pada bentuk kalimat tidak bersubjek.

"Menurut sy sbnrnya pemerintah pusat sudah bekerja dgn baik, hanya dibawanya pemerintah pusat yakni pemerintah daerah itu yg pejabatnya lgi cari panggung politiknya."

Data di atas merupakan kesalahan berbahasa tataran sintaksis dalam bidang kalimat pada bentuk penggandaan subjek. Berdasarkan teori analisis kesalahan berbahasa yang digunakan, kalimat tersebut mengalami ketidakjelasan dalam penekanan subjek. Pemerintah pusat dan pemerintah daerah yang bercetak miring membuat kalimat tersebut memiliki subjek yang ganda. Penggandaan subjek membuat tidak jelasnya bagian dalam kalimat yang memerlukan tekanan, perbaikan kalimat tersebut menjadi :

"Menurut saya sebenarnya pemerintah pusat sudah bekerja dengan baik, hanya saja pemerintah daerah yang pejabatnya lagi cari panggung politiknya."

\section{Kalimat yang Tidak Logis}

Berdasarkan hasil identifikasi, ditemukan empat data kesalahan dalam bidang kalimat pada bentuk kalimat yang tidak logis.

"Korona $80 \%$ aja bukan $98 \%$ tingkat kesembuhannya."

Data di atas merupakan kesalahan berbahasa tataran sintaksis dalam bidang kalimat pada bentuk kalimat tidak logis. Berdasarkan teori analisis kesalahan berbahasa yang digunakan, kalimat tidak logis terbentuk karena penulis kurang teliti serta kurang berhati-hati dalam memilih kata. Penambahan kata melainkan membuat kalimat di atas menjadi logis. Perbaikan data kesalahan tersebut ialah :
"Tingkat kesembuhan corona bukan 98\% melainkan hanya $80 \%$."

Data lainnya ialah :

"Termometer digital itu kadang enggak efektif hasilnya lebih akurat pakai yang digital."

Data di atas merupakan kesalahan berbahasa tataran sintaksis dalam bidang kalimat pada bentuk kalimat tidak logis. Berdasarkan teori analisis kesalahan berbahasa yang digunakan, kalimat tidak logis terbentuk karena penulis kurang teliti serta kurang berhati-hati dalam memilih kata. Kata digital yang bercetak miring dianggap tidak logis, karena di akhir kalimat sudah menggunakan "digital" sehingga dianggap tidak sejalan karena kalimat tersebut merupakan perbandingan antara dua jenis termometer. Kata digital lebih baik diganti dengan jenis termometer lainnya, sehingga kalimat tersebut menjadi logis. Perbaikan kalimat tersebut menjadi :

"Termometer air raksa itu kadang tidak efektif hasilnya lebih akurat pakai termometer digital."

\section{Kalimat Ambiguitas}

Berdasarkan hasil identifikasi, ditemukan satu data kesalahan dalam bidang kalimat pada bentuk kalimat ambiguitas.

"Hongkong juga yg kena corona dah ribuan, jepang korsel hampir sama."

Data di atas merupakan kesalahan berbahasa tataran sintaksis dalam bidang kalimat pada bentuk kalimat ambiguitas. Berdasarkan teori analisis kesalahan yang digunakan, kalimat ambiguitas ialah kegandaan arti pada sebuah kalimat. Kalimat yang ambiguitas membuat pembaca menjadi ragu ataupun tidak paham sama sekali terhadap yang disampaikan dalam kalimat tersebut. Kalimat yang ambiguitas dapat disebabkan oleh intonasi yang tidak tepat, pemakaian kata yang bersifat polisemi, serta struktur dan urutan dalam kalimat yang tidak tepat. Data di atas memiliki kegandaan arti yaitu, 
Jepang dan Korea Selatan yang terinfeksi corona jumlahnya hampir sama yaitu ribuan dan Jepang dan Korea Selatan yang terinfeksi corona jumlahnya hampir sama namun tidak ribuan. Perbaikan data di atas agar menjadi kalimat tidak ambiguitas ialah :

(a) "Hongkong juga yang kena corona udah ribuan, Jepang dan Korsel hampir sama yang terinfeksi corona juga ribuan."

(b) "Hongkong juga yang kena corona udah ribuan, Jepang dan Korsel hampir sama jumlah yang terinfeksi corona namun tidak sampai ribuan."

\section{Penghilangan Konjungsi}

Berdasarkan hasil identifikasi, ditemukan empat data kesalahan dalam bidang kalimat pada bentuk penghilangan konjungsi.

"Bu Ninik statementnya persis banget pas saya wawancara hari senin pagi."

Berdasarkan teori analisis kesalahan berbahasa yang digunakan, terdapat beberapa bagian kalimat yang harus menggunakan konjungsi. Bagian kalimat "...persis banget sesuai yang saya wawancara...", penggunaan konjungsi yang bercetak miring dapat menjadi perbaikan untuk bentuk kesalahan penghilangan konjungsi, sehingga perbaikan kalimat di atas menjadi :

"Bu Ninik statementnya persis banget sesuai yang saya wawancara hari senin pagi."

Data lainnya ialah :

"Masyarakat semakin ragu kinerja pemerintah."

Berdasarkan teori analisis kesalahan berbahasa yang digunakan, terdapat bagian kalimat yang harus menggunakan konjungsi. Bagian kalimat tersebut ialah "...ragu dengan kinerja pemerintah." Penggunaan konjungsi yang bercetak miring dapat menjadi perbaikan untuk bentuk kesalahan penghilangan konjungsi, sehingga perbaikan kalimat di atas menjadi :
"Masyarakat semakin ragu dengan kinerja pemerintah."

\section{Penggunaan Konjungsi yang Berlebihan}

Berdasarkan hasil identifikasi, ditemukan empat data kesalahan dalam bidang kalimat pada bentuk penggunaan konjungsi yang berlebihan.

"Mata Najwa selalu menghadirkan berita yang detail. Yang tersembunyi dibuat transparan. Yang membelok dibuat ke jalur yang benar."

Berdasarkan teori analisis kesalahan berbahasa yang digunakan, penggunaan konjungsi yang berlebihan disebabkan oleh kurang berhati-hatinya penulis sehingga tanpa sadar menggunakan konjungsi secara berlebihan. Penggunaan konjungsi yang bercetak miring "yang tersembunyi dibuat transparan, yang membelok dibuat ke jalur yang benar." dapat dilakukan perbaikan dengan cara menghilangkan salah satu konjungsi. Perbaikan kalimat tersebut menjadi :

"Mata Najwa selalu menghadirkan berita yang detail. Hal tersembunyi dibuat transparan. Hal yang membelok dibuat ke jalur yang benar."

\section{Urutan yang Tidak Paralel}

Berdasarkan hasil identifikasi, ditemukan dua data kesalahan dalam bidang kalimat pada bentuk urutan yang tidak paralel.

"FYI ya guys, di Jawa Timur Sudah siaga, setiap RS yang ditunjuk oleh Kemenkes sudah mempersiapkan dg baik dan disosialisasikan kpd masyarakat."

Berdasarkan teori analisis kesalahan berbahasa yang digunakan, dalam sebuah kalimat unsur yang rinci harus dibuat paralel sebaik mungkin. Unsur yang bercetak miring merupakan unsur yang tidak paralel. Perbaikan yang dapat dilakukan pada unsur tersebut ialah :

"FYI ya guys, di Jawa Timur sudah siaga setiap RS yang ditunjuk oleh Kemenkes sudah mempersiapkan dengan baik dan 
mensosialisasikan kepada masyarakat."

Data lainnya ialah :

"Virus Corona tertular melalui lendir atau mungkin fases penderita korona yang entah dalam kejadian tertentu mengenai dan memasuki mulut atau hidung orang lain, sehingga orang tersebut tertular corona."

Berdasarkan teori analisis kesalahan berbahasa yang digunakan, dalam sebuah kalimat unsur yang rinci harus dibuat paralel sebaik mungkin. Unsur yang bercetak miring merupakan unsur yang tidak paralel. Perbaikan yang dapat dilakukan pada unsur tersebut ialah :

"Virus Corona menular melalui lendir atau mungkin fases penderita corona yang entah dalam kejadian tertentu mengenai dan memasuki mulut atau hidung orang lain, sehingga orang tersebut tertular corona."

\section{Penggunaan Istilah Asing}

Berdasarkan hasil identifikasi, ditemukan 30 data kesalahan dalam bidang kalimat pada bentuk penggunaan istilah asing.

"Goverment membagikan masker gratis masing-masing houseshold 4 lembar dan bisa diambil di lokasi terdekat dari rumah."

Berdasarkan teori analisis kesalahan berbahasa yang digunakan, penggunaan istilah asing dalam sebuah kalimat kemungkinan terjadi karena pengguna bahasa ingin memperlihatkan kebolehan ataupun sikap intelektualnya kepada pembaca. Penggunaan istilah asing goverment pada kalimat di atas dapat diganti dengan padanan bahasa Indonesia pemerintah dan household diganti dengan padanan bahasa Indonesia rumah tangga karena memiliki arti yang sama sehingga tidak merubah makna kalimat.

"Pemerintah membagikan masker gratis masing-masing rumah tangga 4 lembar dan bisa diambil di lokasi terdekat dari rumah."
Data lainnya ialah :

"Begitu ada panic buying, besoknya langsung di restock dan di batasi pembelian bahan makanan."

Berdasarkan teori analisis kesalahan berbahasa yang digunakan, penggunaan istilah asing dalam sebuah kalimat kemungkinan terjadi karena pengguna bahasa ingin memperlihatkan kebolehan ataupun sikap intelektualnya kepada pembaca. Penggunaan istilah asing panic buying pada kalimat di atas dapat diganti dengan padanan bahasa Indonesia kepanikan membeli dan restock diganti dengan padanan bahasa Indonesia disediakan kembali karena memiliki arti yang sama sehingga tidak merubah makna kalimat.

"Begitu ada kepanikan membeli, besoknya langsung disediakan kembali dan dibatasi pembelian bahan makanan."

Data lainnya ialah :

"Intinya masyarakat yang bijaksana adalah yg tidak membuat gaduh, ttp tenang jangan saling menyalahkan, lalu protect diri dan lingkungan, ttp melakukan pola hidup sehat, di tambah berdoa."

Berdasarkan teori analisis kesalahan berbahasa yang digunakan, penggunaan istilah asing dalam sebuah kalimat kemungkinan terjadi karena pengguna bahasa ingin memperlihatkan kebolehan ataupun sikap intelektualnya kepada pembaca. Penggunaan istilah asing protect pada kalimat di atas dapat diganti dengan padanan bahasa Indonesia melindungi karena memiliki arti yang sama sehingga tidak merubah makna kalimat.

"Intinya masyarakat yang bijaksana adalah yang tidak membuat gaduh, tetap tenang jangan saling menyalahkan, lalu melindungi diri dan lingkungan, tetap melakukan pola hidup sehat, ditambah berdoa."

Data lainnya ialah :

"Checkpoint bandara pun kurang ketat."

Berdasarkan teori analisis kesalahan 
berbahasa yang digunakan, penggunaan istilah asing dalam sebuah kalimat kemungkinan terjadi karena pengguna bahasa ingin memperlihatkan kebolehan ataupun sikap intelektualnya kepada pembaca. Penggunaan istilah asing checkpoint pada kalimat di atas dapat diganti dengan padanan bahasa Indonesia titik pemeriksaan karena memiliki arti yang sama sehingga tidak merubah makna kalimat.

"Titik pemeriksaan bandarapun kurang ketat."

\section{Data lainnya ialah :}

"Krn biar kita sebagai tetangga bisa aware periksa."

Data di atas merupakan kesalahan berbahasa tataran sintaksis dalam bidang kalimat pada penggunaan istilah asing. Berdasarkan teori analisis kesalahan berbahasa yang digunakan, penggunaan istilah asing dalam sebuah kalimat kemungkinan terjadi karena pengguna bahasa ingin memperlihatkan kebolehan ataupun sikap intelektualnya kepada pembaca. Penggunaan istilah asing aware pada kalimat di atas dapat diganti dengan padanan bahasa Indonesia sadar karena memiliki arti yang sama sehingga tidak merubah makna kalimat.

"Karena biar kita sebagai tetangga bisa sadar periksa."

Data lainnya ialah :

"Check up didaerah terdampak atau rawan outbreak."

Data di atas merupakan kesalahan berbahasa tataran sintaksis dalam bidang kalimat pada penggunaan istilah asing. Berdasarkan teori analisis kesalahan berbahasa yang digunakan, penggunaan istilah asing dalam sebuah kalimat kemungkinan terjadi karena pengguna bahasa ingin memperlihatkan kebolehan ataupun sikap intelektualnya kepada pembaca. Penggunaan istilah asing check up pada kalimat di atas dapat diganti dengan padanan bahasa Indonesia periksa dan outbreak diganti dengan padanan bahasa Indonesia kejadian luar biasa karena memiliki arti yang sama sehingga tidak merubah makna kalimat.

"Periksa didaerah terdampak atau rawan kejadian luar biasa."

\section{Penggunaan Kata Tanya yang Tidak Perlu}

Berdasarkan hasil identifikasi, ditemukan lima data kesalahan dalam bidang kalimat pada bentuk penggunaan kata tanya yang tidak perlu.

"Gimana gak pinter ibu ini seorang aktivis migrant care dimana selalu menyuarakan ttg buruh migran."

Berdasarkan teori analisis kesalahan berbahasa yang digunakan, penggunaan kata tanya yang tidak perlu dalam sebuah kalimat dapat terjadi karena kemungkinan besar dipengaruhi oleh bahasa asing, ataupun kebiasaan yang dibiarkan dalam penggunaan kata tanya yang penempatannya tidak tepat dan sebaiknya dapat diganti dengan padanan bahasa Indonesia yang lebih tepat, perbaikan data di atas ialah :

"Gimana gak pinter ibu ini seorang aktivis migrant care yang selalu menyuarakan tentang buruh migran."

Data lainnya ialah :

"Kenanya di Iran, positif di New Zealand. Yang jadi concern adalah berarti ketika masuk Bali masih dalam masa inkubasi virus, dimana tidak ada gejala sakit."

Berdasarkan teori analisis kesalahan berbahasa yang digunakan, penggunaan kata tanya yang tidak perlu dalam sebuah kalimat dapat terjadi karena kemungkinan besar dipengaruhi oleh bahasa asing, ataupun kebiasaan yang dibiarkan dalam penggunaan kata tanya yang penempatannya tidak tepat dan sebaiknya dapat diganti dengan padanan bahasa Indonesia yang lebih tepat, perbaikan data di atas ialah :

"Kenanya di Iran, positif di New Zealand. Yang jadi concern adalah berarti ketika masuk Bali masih dalam masa inkubasi 
virus, pada saat itu tidak ada gejala sakit."

Data lainnya ialah :

"Aneh pertanyaan kemana jawabannya kemana."

Data di atas merupakan kesalahan berbahasa tataran sintaksis dalam bidang kalimat pada penggunaan kata tanya yang tidak perlu. Berdasarkan teori analisis kesalahan berbahasa yang digunakan, penggunaan kata tanya yang tidak perlu dalam sebuah kalimat dapat terjadi karena kemungkinan besar dipengaruhi oleh bahasa asing, ataupun kebiasaan yang dibiarkan dalam penggunaan kata tanya yang penempatannya tidak tepat dan sebaiknya dapat diganti dengan padanan bahasa Indonesia yang lebih tepat, perbaikan data di atas ialah :

"Aneh pertanyaan dan jawabannya tidak selaras."

Setyawati dalam (Alber \& Rhani Febria, 2018) kesalahan berbahasa merupakan penggunaan bahasa baik secara lisan maupun tulisan yang menyimpang dari faktor-faktor penentu berkomunikasi atau menyimpang dari norma kemasyarakatan dan menyimpang dari kaidah tata bahasa Indonesia. Melalui analisis di atas penulis berfokus kepada bahasa tulisan yang ditinggalkan oleh masyrakat di kolom komentar. Bahasa tulisan tersebut dianggap menyimpang dari fakto-faktor penentu komunikasi ataupun kaidah kebahasaan. Tulisan-tulisan tersebut ditetapkan dalam bentuk-bentuk kesalahan berbahasa tataran sintaksis.

\section{SIMPULAN}

Berdasarkan hasil penelitian yang dilakukan ditemukan 67 data kesalahan berbahasa tataran sintaksis dalam bidang kalimat. sembilan data bentuk kesalahan kalimat tidak bersubjek, satu data bentuk kesalahan kalimat tidak berpredikat, lima data bentuk kesalahan kalimat buntung, satu data bentuk kesalahan penggandaan subjek, empat data bentuk kesalahan kalimat tidak logis, satu data bentuk kesalahan kalimat ambiguitas, empat data bentuk kesalahan penghilangan konjungsi, empat data bentuk kesalahan penggunaan konjungsi yang berlebihan, dua data bentuk kesalahan urutan yang tidak paralel, 30 data bentuk kesalahan penggunaan istilah asing dan lima data bentuk kesalahan penggunaan kata tanya yang tidak perlu.

\section{REFERENSI}

Alber, \& Rhani Febria. (2018). Analisis Kesalahan Berbahasa Tataran Sintaksis Dalam Kumpulan Makalah Mahasiswa Universitas Islam Riau. Jurnal Geram, 6, (78).

Alisjahbana, S. T. (1978). Tata Bahasa Indonesia I. Jakarta: Dian Rakyat.

Alwi, H. (1989). Tata Bahasa Baku Bahasa Indonesia. Jakarta: Balai Pustaka.

Chaer, A. (2003). Linguistik Umum. Jakarta: Rineka Cipta.

Fokker, A. (1978). Pengantar Sintaksis Indonesia. Jakarta: Pradnya Paramita.

Gani, E. (2019). Komponen-komponen Karya Tulis Ilmiah. Bandung: Pustaka Reka Cipta.

Moleong, L. (2007). Metode Penelitian Kualitatif. Bandung: Remaja Rosdakarya.

Sebayang, S. K. (2019). Analisis Kesalahan Berbahasa pada Sosial Media Instagram dalam Postingan, Komentar, dan Cerita Singkat. Jurnal Serunai Bahasa Indonesia, 16(1), 49-57.

Setiawan, K. E. P., \& Zyuliantina, W. (2020). Analisis Kesalahan Berbahasa Indonesia Pada Status dan Komentar di Facebook. Tabasa: Jurnal Bahasa, Sastra Indonesia, dan Pengajarannya, 1(1), 96-109.

Setyawati, N. (2013). Analisis Kesalahan Berbahasa Indonesia. Surakarta:Yuma Pustaka.

Sinaga, M. (2017). Sintaksis Bahasa Indonesia. Fakultas Keguruan dan Ilmu Pendidikan Universita Riau.

Sugiyono. (2012). Metode Penelitian Kuantitatif Kualitatif dan $R \& D$. Bandung: Alfabet. 